\title{
Analisis Perbedaan Risk dan Return antara Saham Syariah dan Konvensional di Bursa Efek Indonesia
}

\author{
Lestari \\ Atty Erdiana \\ Manajemen, Universitas Wijaya Kusuma Surabaya, Indonesia \\ Korespondensi penulis: lestarife@uwks.ac.id
}

\begin{abstract}
This study purposed to compare the Risk and Return between Islamic and conventional stocks listed on the Indonesia Stock Exchange. The object of this research is sharia and conventional stocks listed on the Indonesia Stock Exchange. The sampling method used in this study was purposive sampling with a sample size of 50 Islamic stocks and 50 conventional stocks. This research focused on the study of Islamic and conventional stock price data from 2015 to 2018. The analysis technique used to test the level of differences in risk and return in Islamic and conventional stock groups was the independent sample t-test. The results showed that there was no significant difference between the average return on Islamic and conventional stocks. Meanwhile, the results of the risk comparison of the two groups of stocks were heterogeneous (not the same) so that the risk of the two stocks cannot be compared.
\end{abstract}

Keywords: Conventional stock; Return; Risk; Sharia stock.

Abstrak. Penelitian ini bertujuan untuk membandingkan Risk dan Return antara saham syariah dan konvensional yang tercatat di Bursa Efek Indonesia (BEI). Obyek penelitian ini adalah saham syariah dan konvensional yang go public di Bursa Efek Indonesia. Metode sampling yang digunakan dalam penelitian ini adalah purposive sampling dengan jumlah sampel adalah 50 saham syariah dan 50 saham konvensional. Penelitian ini fokus pada kajian data harga saham syariah dan konvensional dari tahun 2015 sampai dengan 2018. Teknik analisis yang digunakan untuk menguji tingkat perbedaan Risk dan Return pada kelompok saham syariah dan konvensional adalah uji independent sample t-test. Hasil penelitian menunjukkan bahwa tidak ada perbedaan signifikan antara rata-rata return pada saham syariah dan konvensional, sedangkan hasil perbandinagn risk pada kedua kelompok saham tersebut bervariasi atau heterogen (tidak sama). Dengan demikian, risk pada kedua saham tersebut tidak dapat dibandingkan.

Kata kunci: Risiko; Return; Saham konvensional; Saham syariah. 


\section{LATAR BELAKANG}

Seoarng investor muslim mempunyai berbagai alternatif investasi yang tidak bertentangan dengan prinsip Islam, yaitu investasi yang sesuai dengan ajaran Islam atau tidak bertentangan dengan Al-Quran dan Hadist. Beberapa alternatif investasi berbasis syariah ditawarkan dengan tingkat risk dan return yang tidak berbeda dengan alternatif investasi berbasis konvensional. Kondisi ini menjadikan investor muslim mempunyai alternatif investasi yang halal dengan tingkat return setara dengan investasi berbasis konvensional (Muthoharoh \& Sutapa, 2014; Listyawati \& Nurchayati, 2020). Dengan demikian, seorang muslim dapat melakukan aktivitas ekonomi dan bisnisnya dengan berpegang pada prinsip-prinsip yang tidak bertentangan dengan aturan syariat agama Islam atau Islamic principles. Setiap muslim mendapatkan hasil usaha dengan menanggung suatu risiko dan menganggap uang sebagai alat tukar, dan bukan sebagai komoditi atau benda (Sutedi, 2011).

Investasi merupakan salah satu kegiatan bisnis yang dilakukan juga oleh seorang muslim. Bagi orang muslim, memilih investasi halal merupakan sebuah keharusan sesuai tuntunan agama. Namun, perhitungan terhadap tingkat pengembalian (return) investasi juga sama pentingnya. Investasi bagi orang muslim merupakan aktivitas ekonomi yang harus dilaksanakan sesuai prinsip-prinsip ekonomi Islam (Sutedi, 2011). Salah satu alternatif investasi bagi kaum muslim adalah sekuritas syariah di pasar modal. Emiten di pasar modal dapat menerbitkan sekuritas konvensional dalam bentuk saham dan obligasi, maupun sekuritas syariah dalam bentuk saham syariah dan sukuk atau obligasi syariah (Sutedi, 2011). Emiten yang menerbitkan sekuritas syariah adalah mereka yang telah mendapatkan rekomendasi dari Majelis Ulama Indonesia (MUI) (Faqih, 2018).

Saat ini, para investor, termasuk investor muslim, memilih investasi yang lebih memprioritaskan keuntungan. Meraka kurang peduli pada obyek investasi yang mereka pilih . Seorang muslim seharusnya tidak hanya memikirkan tingkat keuntungan semata, tetapi juga kehalalan dan kebarokahan investasinya. Penelitian ini bertujuan untuk membandingkan risk dan return saham syariah dan konvensional untuk memberikan referensi kepada investor muslim di dalam memilih alternatif investasi yang menguntungkan dan halal. Perkembangan saham syariah di BEI diprediksikan semakin baik, karena mayoritas penduduk Indonesia adalah muslim dan kesadaran mereka berinvestasi secara syariah mulai meningkat. Hal ini dapat membuka peluang lebih luas bagi investor muslim untuk memilih altenatif investasi di pasar modal sesuai tuntutan agama dan juga menguntungkan. Sebuah tantangan baru bagi para investor muslim, bagaimana perbedaan risk dan return investasi pada saham syariah dan konvensional. Dari uraian tersebut, penelitian ini bertujuan untuk mengetahui perbedaan antara risk dan return pada saham syariah dan konvensional yang tercatat di Bursa Efek Indonesia (BEI).

\section{KAJIAN TEORITIS}

\section{Pasar Modal (Capital Market)}

Pasar modal (capital market) adalah sebuah pasar untuk memperjualbelikan berbagai instrumen finansial/keuangan jangka panjang, baik dalam berupa surat hutang atau surat berharga obligasi, ekuitas atau surat berharga saham, reksadana, dan instrumen derivatif, serta instrumen-instrumen finansial jangka panjang lainnya (Husnan, 
2008). Pasar modal merupakan sarana untuk mendapatkan pendanaan bagi perusahaan (emiten) atau pun institusi lainnya, misalnya pemerintah, serta menjadi sarana alternatif untuk aktivitas berinvestasi (Bursa Efek Indonesia, 2020). Jadi, pasar modal lebih banyak berperan untuk memberikan fasilitasi berbagai prasarana dan sarana aktivitas jual beli sekuritas, serta aktivitas-aktivitas terkait lainya berinvestasi (Bursa Efek Indonesia, 2020). Undang-Undang nomor 8 tahun 1995 tentang pasar modal menyatakan bahwa pasar modal merupakan kegiatan yang berkaitan dengan penawaran umum dan perdagangan efek, perusahaan publik yang berkaitan dengan efek yang diterbitkannya, serta lembaga dan profesi yang berkaitan dengan Efek (Otoritas Jasa Keuangan, 2020a).

Bagi perkembangan perekonomian negara. pasar modal memegang dua peranan atau fungsi sangat penting berinvestasi (Bursa Efek Indonesia, 2020). Pertama, pasar modal berperan sebagai sarana untuk memperoleh pendanaan bagi kegiatan usaha atau sarana pengumpulan dana dari masyarakat sebagai investor yang dibutuhkan oleh perusahaan (emiten) untuk kegiatan operasional mereka. Dengan demikian, dana yang dikumpulkan dari masyarkat (investor) tersebut akan digunakan oleh perusahaan (emiten) dalam kegiatan operasionalnya. Dana investasi tersebut dapat digunakan untuk pengembangan usaha, pengembangan produk, memperbaiki struktur modal, dan kegiatan operasional perusahaan lainnya. Kedua, pasar modal dapat menjadi alternatif kegiatan investasi pada instrumen finansial, seperti obligasi, saham, reksadana, dan instrumen sekuritas lainnya bagi dari masyarakat, selain perbankan dan lembaga keuangan lainnya. Dengan keberadaan pasar modal, masyarakat dapat melakukan kegiatan investasi dengan tetap mempertimbangkan risk dan return yang harus ditanggung dari intrumen-intrumen yang ditawarkannya.

\section{Saham}

Menurut Husnan (2008), saham merupakan secarik kertas yang menunjukkan adanya hak investor sebagai pemilik kertas tersebut untuk mendapatkan hak atas kekayaan atau prospek dari institusi yang menerbitkan dan berbagai kondisi investor dalam menjalankan hak yang dimilikinya. Menurut Fahmi (2012), saham merupakan sebuah instrumen pasar modal yang paling diminati oleh investor, karena dapat memberikan tingkat keuntungan yang lebih menarik.

Berdasarkan pengertian-pengertian tersebut, saham dapat disebut sebagai surat bukti yang dipegang oleh masyarakat (investor) sebagai bukti bahwa ia ikut andil memiliki perusahaan yang menerbitkan surat bukti (saham) tersebut (Husnan, 2008). Surat sebagai tanda bukti berupa saham merupakan surat berharga yang mencantumkan nama perusahaan, nilai nominal, dan hak maupun kewajiban yang harus dipatuhi oleh pemegang/pemiliknya. Saham merupakan surat berharga yang paling banyak diminati investor (Husnan, 2008). Minat atas saham disebabkan oleh pemberian return atau tingkat pengembalian yang lebih manarik dibandingkan dengan surat berharga atau intrumen finansial jangka panjang lainnya (Tandelilin, 2001).

Konsep dasar manajemen keuangan menyatakan bahwa tujuan manajemen keuangan adalah maksimalisasi nilai perusahaan, sehingga perusahaan yang sudah go public akan berupaya memaksimalkan nilai perusahaan dengan memaksimalkan harga saham yang diterbitkannya di pasar modal. Setiap kebijakan yang dilakukan perusahaan ditujukan untuk memaksimalkan kekayaan masyarakat pemegang saham (investor). 
Sartono (2008) menyatakan bahwa harga saham didasarkan atas mekanisme supply dan demand di pasar modal.

\section{Tingkat Keuntungan (Return) Saham}

Tingkat keuntungan yang diperoleh dari investasi saham atau return saham adalah perubahan harga saham pada periode tertentu $(\mathrm{t})$ dengan harga saham periode sebelumnya (t-1) (Hanafi \& Halim, 2012). Jika perubahan harga saham tinggi, maka return saham yang dihasilkan akan tinggi pula atau sebaliknya. Return saham merupakan faktor yang memberikan motivasi bagi masyarakat (investor) sebagai imbalan atas investasinya di pasar modal dan keberanian menanggung risiko investasi yang telah dipilih. Dua komponen terpenting pada return saham (Jogiyanto, 2008) adalah:

1. Yield. Yield merupakan komponen return yang menggambarkan pendapatan atau aliran kas yang diperoleh secara periodik dari kegiatan investasi yang telah dilakukan. Yield merupakan angka nol dan angka positif (+).

2. Capital gain/loss. Capital gain/ loss merupakan selisih kenaikan atau penurunan harga saham. Kenaikan harga saham mencerminkan keuntungan investasi (capital gain) dan penurunan harga saham mencerminkan kerugian (capital loss). Capital gain/loss dapat berupa angka postif (+), angka nol (0), atau angka minus (-). Rumus sistematik return saham dapat diformulasikan pada persamaan [1]:

$$
\text { Total Return = Yield }+ \text { Capital gain/loss }
$$

\section{Risiko (Risk) Saham}

Menurut Jogiyanto (2008), return dan risiko saham memiliki hubungan yang positif, yaitu semakin tinggi tingkat risiko sebuah investasi saham, maka semakin tinggi pula ekspektasi returnnya (expected return), atau sebaliknya. Saat memilih investasi, investor berusaha memilih investasi pada portofolio yang optimal. Portofolio saham yang optimal adalah kombinasi investasi yang menawarkan tingkat risiko tertentu dengan ekspektasi return optimal, atau tingkat risiko minimal dengan eskpektasi return tertentu (Jogiyanto, 2008). Risiko investasi diartikan sebagai sebuah ketidakpastian. Menurut Hidayat (2011), risiko saham mengacu adanya varian (penyimpangan) nilai yang diprediksi dengan nilai yang diobservasi.

Pada umumnya, investor menghadapi dua masalah dalam investasi mereka sebagai faktor yang tidak dapat dihindari saat berinvestasi. Risiko di dalam portofolio saham dapat dikelompokkan menjadi dua macam (Husnan, 2008), yaitu:

1. Risiko Sistematik (Systematic Risk). Risiko sistematik atau disebut pula dengan risiko pasar (market risk) merupakan risiko yang selalu ada, meskipun investor melakukan diversifikasi investasi. Besar kecilnya risiko ini dipengaruhi oleh perubahan lingkungan eksternal (kondisi politik, kondisi sosial, kebijakan pajak, kondisi perekonomian, dan lain-lain).

2. Risiko Tidak Sistematik (Unsystematic Risk). Risiko tidak sistematik merupakan risiko saham yang akan terus berkurang, apabila investor melakukan diversifikasi, meskipun tidak mungkin sama dengan nol. Jadi, investor dapat menghindari/mengurangi risiko ini dengan melakukan diversifikasi pada portofolionya. 
Penjumlahan risiko sistematis dan risiko tidak sistematis disebut sebagai risiko total yang ditunjukkan pada Gambar 1 dan menjadi dasar pertimbangan manajer investasi dalam pengambilan keputusan investasinya.

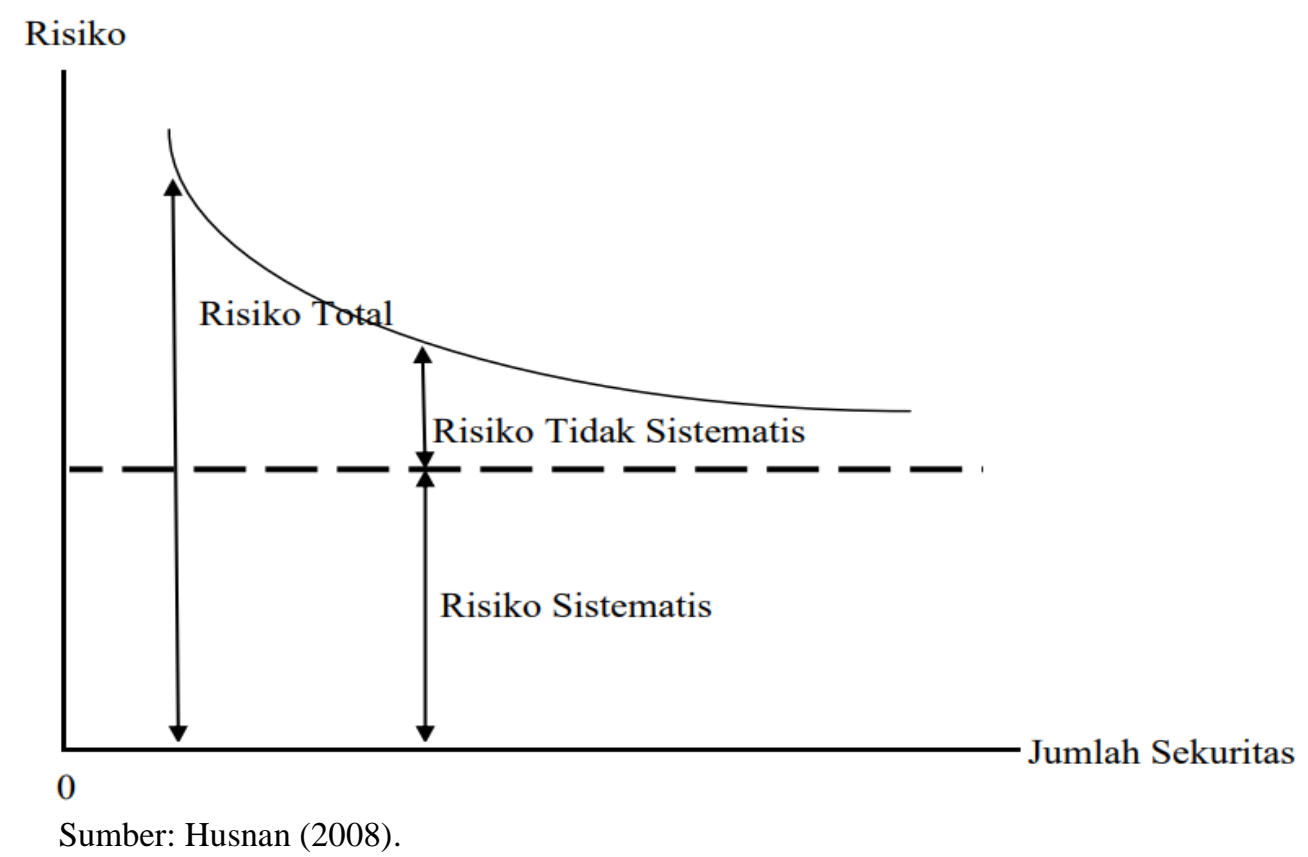

Gambar 1. Bagan Risiko Investasi Sekuritas

\section{Saham Syariah}

Saham sebagai bukti atau sertifikat kepemilikan seseorang atau suatu badan terhadap perusahaan yang menerbitkannya, sehingga saham dapat pula diartikan sebagai keikutsertaan investor sebagai pemodal pada suatu perusahaan emiten dan pemegang saham memiliki klaim atas penghasilan dan aktiva perusahaan tersebut (Umam, 2013). Saham syariah adalah saham yang memiliki karakteristik sesuai syariah Islam (Umam, 2013). Saham syariah juga diartikan sebagai bukti kepemilikan atas suatu perusahaan yang berbentuk perseroan terbatas (PT). Dari sudut pandang fiqh, pada dasarnya saham syariah adalah efek syariah. Saham syariah merupakan salah satu bentuk saham biasa yang memiliki karakteristik khusus berupa kendali ketat atas kehalalan dalam ruang lingkup kegiatan perusahaannya (Umam, 2013).

Sebagai perbandingan, saham konvensional memasukkan seluruh saham yang tercatat di bursa efek dengan mengabaikan aspek halal dan haram pada kegiatan operasionalnya. Pada prinsipnya, saham yang diperdagangkan di bursa efek adalah saham dari perusahaan emiten yang terdaftar (listing) di bursa efek, sehingga saham tersebut telah sesuai aturan yang berlaku atau memenuhi aspek legalitas perdagangan saham. Pada umumnya, saham dikategorikan menjadi dua macam, yaitu saham syariah dan saham non-syariah atau konvensional. Saham syariah adalah sertifikat yang menunjukkan bukti kepemilikan suatu perusahaan yang diterbitkan oleh emiten dengan kegiatan usaha maupun cara pengelolaannya tidak bertentangan dengan prinsip-prinsip syariah (Majelis Ulama Indonesia, 2011). Berdasarkan fatwa Dewan Syariah Nasional Majelis Ulama Indonesia (DSN-MUI), fatwa ditetapkan dalam peraturan Badan Penga- 
was Pasar Modal (BAPEPAM) dan Lembaga Keuangan (LK). Perbedaan saham syariah dan saham konvensional terletak pada kegiatan usaha dan tujuannya. Jenis kegiatan usaha yang bertentangan dengan prinsip-prinsip syariah (Majelis Ulama Indonesia, 2013), antara lain:

a. Usaha perjudian dan permainan yang tergolong judi atau perdagangan yang dilarang.

b. Usaha lembaga keuangan konvensional (ribawi) termasuk perbankan dan asuransi konvensional.

c. Usaha yang memproduksi, mendistribusi, dan memperdagangkan makanan dan minuman yang dikategorikan haram.

DSN-MUI juga menetapkan kriteria saham yang termasuk kategori syariah, antara lain:

a. Tidak melakukan kegiatan usaha sebagaimana kegiatan usaha yang dikategorikan bertentangan dengan prinsip syariah.

b. Tidak melakukan perdagangan yang tidak disertai dengan penyerahan barang atau jasa dan perdagangan dengan penawaran dan permintaan palsu.

c. Tidak melebihi rasio keuangan sebagai pasar modal yang menerapkan prinsipprinsip syariah dalam kegiatan transaksi ekonominya dan terlepas dari hal-hal yang dilarang agama, seperti: riba, perjudian, spekulasi, dan lain-lain.

Berdasarkan Peraturan Otoritas Jasa Keuangan (OJK) nomor 35/POJK.04/2017 tentang Kriteria dan Penerbitan Daftar Efek Syariah (Otoritas Jasa Keuangan, 2020b), OJK telah menetapkan penilaian kriteria yang dikategorikan saham syariah yaitu: (1) Syarat-syarat transaksi harus sesuai prinsip syariah; (2) Tidak ada unsur yang mengandung kedzoliman; (3) Tidak ada praktik bunga atau riba; (4) Tidak merugikan pihak lain maupun diri sendiri; (5) Terhindar dari unsur gharar (penipuan); (6) Tidak ada unsur-unsur yang mengandung materi haram; dan (7) Tidak ada unsur-unsur yang mengandung maisyir (judi). Berdasarkan Keputusan Dewan Komisioner OJK nomor 24/D.04/2018 (Otoritas Jasa Keuangan, 2020c), OJK mencatat sebanyak 619 saham yang diperdagangkan di BEI. Dari jumlah tersebut, 338 saham $(54,60 \%)$ di antaranya adalah saham syariah.

\section{METODE PENELITIAN}

\section{Populasi dan Sampel}

Sugiyono (2007) menyatakan bahwa populasi adalah wilayah generalisasi yang terdiri atas obyek atau subyek yang mempunyai kualitas dan karakteristik tertentu dan ditetapkan oleh peneliti untuk diteliti lebih lanjut dan diambil kesimpulan. Dalam penelitian ini, populasi yang diteliti adalah seluruh saham perusahaan yang terdaftar di Bursa Efek Indonesia tahun 2015-2018. Jumlah saham di Bursa Efek Indonesia sampai dengan tahun 2018 yang masih aktif tercatat sebanyak 619 saham. Dari jumlah saham yang tercatat tersebut, 338 saham di antaranya adalah saham syariah (Bursa Efek Indonesia, 2020).

Sampel adalah sebagian dari jumlah dan karakteristik yang dimiliki oleh sebuah populasi (Sugiyono, 2007). Teknik pengambilan sampel dalam penelitian ini dilakukan dengan metode purposive sampling, yaitu menentukan sampel penelitian berdasarkan pertimbangan atau kriteria tertentu sesuai dengan tujuan penelitian. Kriteria yang ditetapkan dalam dalam menentukan sampel dalam penelitian ini adalah saham yang masih aktif di Bursa Efek Indonesia (BEI) sampai dengan tahun 2018 berdasarkan 
Keputusan Dewan Komisioner OJK nomor 24/D.04/2018 (Otoritas Jasa Keuangan, 2020c). Fraenkel dan Wallen (1993) memberikan panduan bahwa ukuran sampel untuk sebuah penelitian kausal-perbandingan jumlahnya minimal 30 sampel setiap kelompok. Pada penelitian ini, sampel yang digunakan sebanyak 50 saham untuk masing-masing kelompok, yaitu saham syariah dan saham konvensional.

\section{Metode Pengumpulan Data}

Menurut Hamidi (2004), metode dokumentasi adalah informasi yang berasal dari catatan penting, baik dari lembaga atau organisasi maupun perorangan. Metode dokumentasi dalam penelitian ini merupakan pengambilan dokumen dan laporan untuk memperkuat hasil penelitian. Menurut Sugiyono (2007), dokumentasi dapat berbentuk tulisan, gambar, atau karya-karya monumental seseorang. Metode pengumpulan data merupakan salah satu aspek yang berperan penting dalam kelancaran dan keberhasilan penelitian. Teknik pengumpulan data yang digunakan dalam penelitian ini adalah teknik dokumentasi, sedangkan dokumen yang digunakan adalah laporan kinerja keuangan perusahaan yang diterbitkan oleh BEI. Teknik dokumentasi adalah proses mencari data mengenai hal-hal atau variabel-variabel berupa catatan, buku, surat kabar, majalah, atau data yang berkaitan dengan obyek penelitian (Arikunto, 2002).

\section{Alat Analisis Data}

a. Menghitung Return Saham Individual

i. Menghitung Realized return

Return realisasi (realized return) merupakan return yang telah terjadi. Return ini dihitung dengan menggunakan data historis yang formulasinya ditunjukkan pada persamaan [2] (Jogiyanto, 2008).

$$
\text { Ri }=\frac{\text { Pt }- \text { Pt-1 }}{\text { Pt-1 }} \times 100 \%
$$

Keterangan notasi:

$\mathrm{Ri} \quad=$ return realisasi saham $\mathrm{i}$.

Pit $\quad=$ closing price saham i pada periode ke-t.

Pit-1 = closing price saham i pada periode ke-t-1.

\section{ii. Menghitung Expected return}

Return ekspektasi (expected return) adalah return yang diharapkan akan diperoleh investor di masa yang akan datang. Formulasi menghitung expected return ditunjukkan pada persamaan [3].

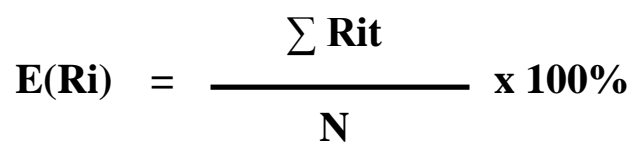

Keterangan notasi:

$\mathrm{E}(\mathrm{Ri})=$ expected return saham $\mathrm{i}$

Rit $=$ return realisasi saham $\mathrm{i}$ pada periode $\mathrm{t}$

$\mathrm{N} \quad=$ jumlah realized return saham $\mathrm{i}$. 
b. Menghitung Risk Saham Individual

Risk saham individual merupakan varian return saham individual selama periode penelitian. Risk Saham secara individual dinyatakan dalam bentuk varian dan standar deviasi saham individual. Varian dan standar deviasi sebagai ukuran risk untuk masing masing saham dihitung dengan formula pada persamaan [4] dan [5].

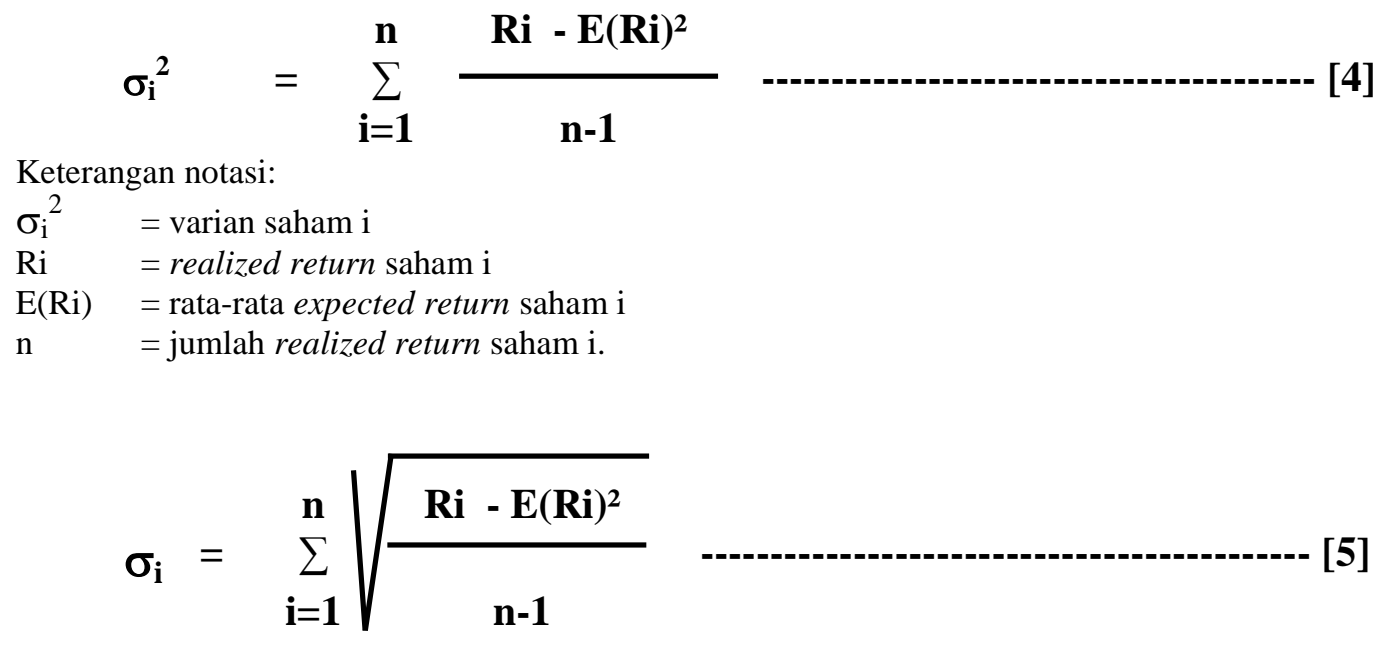

Keterangan notasi:

$\sigma_{\mathrm{i}} \quad=$ standar deviasi saham $\mathrm{i}$.

$\mathrm{Ri} \quad=$ realized return ke-i saham $\mathrm{i}$.

$\mathrm{E}(\mathrm{Ri}) \quad=$ rata-rata expected return saham $\mathrm{i}$.

$\mathrm{N} \quad=$ jumlah realized return saham $\mathrm{i}$.

c. Metode Independent Sample t-test

Teknis analisis data dalam penelitan ini menggunakan statistic parametric (Sugiyono, 2007). Metode analisis yang digunakan untuk menguji hipotesis penelitian ini adalah independent samples t-test dengan bantuan program aplikasi Statistical Product and Service Solution (SPSS) versi 20. Metode tersebut digunakan untuk mengetahui perbedaan rata-rata dua sampel yang berbeda. Independent sample t-test merupakan jenis uji statistika yang bertujuan untuk membandingkan rata-rata dua kelompok data yang tidak saling berpasangan atau tidak saling berkaitan (Santoso, 2014). Dua kelompok data yang tidak saling berpasangan dalam penelitian ini diartikan bahwa penelitian ini menganalisis dua subyek sampel yang berbeda. Dalam penelitian ini, independent sample t-test digunakan untuk mengidentifikasi perbedaan risk dan return saham syariah dan konvensional di Bursa Efek Indonesia.

\section{HASIL DAN PEMBAHASAN}

Penelitian ini menganalisis perbedaan tingkat keuntungan (return) antara saham syariah dan konvensional. Penelitian ini juga membandingkan tingkat risiko (risk) kedua jenis saham tersebut. Penelitian ini memberikan gambaran kinerja kedua saham yang mempunyai karakteristik berbeda. 


\section{Obyek Penelitian}

Jumlah sampel dalam penelitian ini sebanyak 100 saham yang terdiri atas 50 saham syariah dan 50 saham konvensional. Tabel 1 menunjukkan 100 saham yang terpilih dan dianalisis sebagai obyek dalam penelitian ini.

\section{Tabel 1. Seratus Saham sebagai Obyek Penelitian}

\begin{tabular}{|c|c|c|c|c|c|}
\hline No & Kode & Emiten Syariah & No & Kode & Emiten Konvensional \\
\hline 1 & MBAP & Mitrabara Adiperdana & 1 & ABDA & Asuransi Bina Dana Arta \\
\hline 2 & AALI & Astra Agro Lestari & 2 & AGRO & Bank Rakyat Indonesia Agroniaga \\
\hline 3 & ADRO & Adaro Energy & 3 & AHAP & Asuransi Harta Aman Pratama \\
\hline 4 & AKKU & Anugerah Kagum Karya Utama & 4 & AMAG & Asuransi Multi Artha Guna \\
\hline 5 & $\mathrm{AMFG}$ & Asahimas Flat Glass & 5 & ASDM & Asuransi Dayin Mitra \\
\hline 6 & APII & Arita Prima Indonesia & 6 & ASJT & Asuransi Jasa Tania \\
\hline 7 & ASRI & Alam Sutera Realty & 7 & ASMI & Asuransi Kresna Mitra \\
\hline 8 & BEST & Bekasi Fajar Industrial Estate & 8 & ASRM & Asuransi Ramayana \\
\hline 9 & $\mathrm{BOLT}$ & Garuda Metalindo & 9 & $\mathrm{BABP}$ & Bank MNC Internasional \\
\hline 10 & BTON & Betonjaya Manunggal & 10 & $\mathrm{BACA}$ & Bank Capital Indonesia \\
\hline 11 & CANI & Capitol Nusantara Indonesia & 11 & $\mathrm{BBCA}$ & Bank Central Asia \\
\hline 12 & CPIN & Charoen Pokphand Indonesia & 12 & BBHI & Bank Harda Internasional \\
\hline 13 & DGYR & Goodyear Indonesia & 13 & $\mathrm{BBKP}$ & Bank Bukopin \\
\hline 14 & DVLA & Darya-Varia Laboratoria & 14 & $\mathrm{BBNI}$ & Bank Negara Indonesia \\
\hline 15 & ELSA & Elnusa & 15 & BBNP & Bank Nusantara Parahyangan \\
\hline 16 & EXCL & XL Axiata & 16 & BBRI & Bank Rakyat Indonesia \\
\hline 17 & FAST & Fast Food Indonesia & 17 & BBTN & Bank Tabungan Negara \\
\hline 18 & FREN & Smartfren Telecom & 18 & $\mathrm{BCIC}$ & Bank JTrust Indonesia \\
\hline 19 & $\mathrm{HERO}$ & Hero Supermarket & 19 & BDMN & Bank Danamon Indonesia \\
\hline 20 & HITS & Humpuss Intermoda Transportasi & 20 & BFIN & BFI Finance Indonesia \\
\hline 21 & ICON & Island Concepts Indonesia & 21 & $\mathrm{BJBR}$ & BPD Jawa Barat dan Banten \\
\hline 22 & INAI & Indal Aluminium Industry & 22 & $\mathrm{BJTM}$ & BPD Jawa Timur \\
\hline 23 & INDF & Indofood Sukses Makmur & 23 & BKSW & Bank QNB Indonesia \\
\hline 24 & IPOL & Indopoly Swakarsa Industry & 24 & BMRI & Bank Mandiri \\
\hline 25 & ISSP & Steel Pipe Industry of Indonesia & 25 & $\mathrm{BNBA}$ & Bank Bumi Arta \\
\hline 26 & KBLM & Kabelindo Murni & 26 & BNGA & Bank CIMB Niaga \\
\hline 27 & KIAS & Keramika Indonesia Assosiasi & 27 & BNII & Bank Maybank Indonesia \\
\hline 28 & $\mathrm{KOBX}$ & Kobexindo Tractors & 28 & BNLI & Bank Permata \\
\hline 29 & $\mathrm{LION}$ & Lion Metal Works & 29 & BSWD & Bank of India Indonesia \\
\hline 30 & LPLI & Star Pacific & 30 & BTPN & Bank Tabungan Pensiunan Nasional \\
\hline 31 & MLIA & Mulia Industrindo & 31 & CFIN & Clipan Finance Indonesia \\
\hline 32 & MMLP & Mega Manunggal Property & 32 & DLTA & Delta Djakarta \\
\hline 33 & MYOH & Samindo Resources & 33 & GGRM & Gudang Garam \\
\hline 34 & NELY & Pelayaran Nelly Dwi Putri & 34 & HMSP & H.M. Sampoerna \\
\hline 35 & OASA & Protech Mitra Perkasa & 35 & HOME & Hotel Mandarine Regency \\
\hline 36 & PDES & Destinasi Tirta Nusantara & 36 & HOTL & Saraswati Griya Lestari \\
\hline 37 & PGAS & Perusahaan Gas Negara & 37 & INPP & Indonesian Paradise Property \\
\hline 38 & POWR & Cikarang Listrindo & 38 & JIHD & $\begin{array}{l}\text { Jakarta International Hotels \& } \\
\text { Development }\end{array}$ \\
\hline 39 & PTBA & Bukit Asam & 39 & MAMI & Mas Murni Indonesia \\
\hline 40 & PTPP & Pembangunan Perumahan & 40 & MLBI & Multi Bintang Indonesia \\
\hline 41 & RANC & Supra Boga Lestari & 41 & PGLI & Pembangunan Graha Lestari Indah \\
\hline 42 & SCBD & Danayasa Arthatama & 42 & PNSE & Pudjiadi \& Sons \\
\hline 43 & SIDO & $\begin{array}{l}\text { Industri Jamu dan Farmasi Sido } \\
\text { Muncul }\end{array}$ & 43 & PSKT & Red Planet Indonesia \\
\hline 44 & SKBM & Sekar Bumi & 44 & RMBA & Bentoel Internasional Investama \\
\hline 45 & SMRU & SMR Utama & 45 & SHID & Hotel Sahid Jaya International \\
\hline 46 & SRTG & Saratoga Investama Sedaya & 46 & TFA & Tifa Finance \\
\hline 47 & TOBA & Toba Bara Sejahtra & 47 & TRUS & Trust Finance Indonesia \\
\hline 48 & TPIA & Chandra Asri Petrochemical & 48 & VINS & Victoria Insurance \\
\hline 49 & UNVR & Unilever Indonesia & 49 & VRNA & Verena Multi Finance \\
\hline 50 & VOKS & Voksel Electric & 50 & WIIM & Wismilak Inti Makmur \\
\hline
\end{tabular}

Sumber: Bursa Efek Indonesia (2020). 


\section{Risk dan Return}

Return saham merupakan hasil keuntungan atau kerugian yang diperoleh investor sebagai akibat dari investasi saham di bursa efek. Semakin tinggi kenaikan harga saham, maka semakin tinggi pula return sahamnya (capital gain), atau sebaliknya. Estimasi return (expected return) individual merupakan persentase rata-rata return realisasi saham individual dibagi jumlah realisasi return saham individual (Jogiyanto, 2008), sedangkan risiko saham merupakan penyimpangan return aktual atas return realisasi. Semakin besar kemungkinan perbedaan return akan semakin besar pula risiko yang ditanggung oleh investor, atau sebaliknya (Pardosi \& Wijayanto, 2015).

Hasil analisis yang dilakukan dalam penelitian ini menunjukkan besarnya return dan risk saham-saham yang menjadi obyek penelitian sebagai berikut:

\section{a. Risk dan Return Saham Syariah}

Tabel 2 menunjukkan saham syariah dengan risiko terbesar adalah saham PT Destinasi Tirta Nusantara (PDES) dengan risiko sebesar 334,031\%, sedangkan saham dengan risiko terendah adalah saham PT Mega Manunggal Property (MMLP) yaitu sebesar 0,109331\%. Beberapa saham dengan risiko di bawah 1 adalah saham-saham PT Alam Sutera Realty (ASRI), PT Bekasi Fajar Industrial Estate (BEST), PT Humpuss Intermoda Transportasi (HITS), PT SMR Utama (SMRU), dan PT Saratoga Investama Sedaya (SRTG) dengan risiko masing-masing 0,454285\%; 0,42972\%; 0,120998\%; $0,125532 \%$; dan $0,662048 \%$.

Tabel 2 juga menunjukkan hasil perhitungan return dan risk saham-saham syariah yang menjadi obyek penelitian. Tabel 2 tersebut menunjukkan bahwa estimasi return tertinggi positif adalah saham PT Destinasi Tirta Nusantara (PDES) dengan estimasi return sebesar 166,33045\% dan estimasi return positif terendah adalah PT Supra Boga Lestari (RANC) dengan estimasi return sebesar 4,432673\%. Di sisi lain, estimasi return tertinggi negatif adalah PT Island Concepts Indonesia (ICON) sebesar -39,6839\% dan estimasi negatif terendah adalah PT Saratoga Investama Sedaya (SRTG) dengan estimasi sebesar $-1,42908 \%$.

Tabel 2. Hasil Analisis Estimasi Risk dan Return Saham Syariah

\begin{tabular}{|c|c|c|c|c|c|c|c|c|c|c|c|}
\hline No & Emiten & Est. Ret & Risiko & No & Emiten & Est. Ret & Risiko & No & Emiten & Est. Ret & Risiko \\
\hline 1 & MBAP & 40,88269 & 11,04579 & 18 & FREN & 18,08706 & 7,339976 & 35 & OASA & 12,1252 & 4,601392 \\
\hline 2 & AALI & 113,027 & 281,6608 & 19 & HERO & $-10,5389$ & 2,260585 & 36 & PDES & 166,3045 & 334,031 \\
\hline 3 & ADRO & 68,0611 & 132,9972 & 20 & HITS & $-2,21258$ & 0,120998 & 37 & PGAS & $-5,22722$ & 5,352445 \\
\hline 4 & $\mathrm{AKKU}$ & 4,521855 & 10,09329 & 21 & ICON & $-39,6839$ & 5,53215 & 38 & POWR & $-15,1856$ & 3,827178 \\
\hline 5 & AMFG & $-15,5132$ & 2,955749 & 22 & INAI & 28,20226 & 4,89965 & 39 & PTBA & 83,14661 & 53,06221 \\
\hline 6 & APII & $-1,88389$ & 7,639395 & 23 & INDF & 15,68651 & 7,017558 & 40 & PTPP & $-19,6297$ & 2,664382 \\
\hline 7 & ASRI & $-2,86643$ & 0,454285 & 24 & IPOL & 17,44999 & 26,42268 & 41 & RANC & 4,432673 & 15,03798 \\
\hline 8 & BEST & $-10,6601$ & 0,42972 & 25 & ISSP & $-20,1642$ & 5,634329 & 42 & SCBD & 20,32717 & 9,39018 \\
\hline 9 & BOLT & $-4,27127$ & 5,055996 & 26 & KBLM & 29,32355 & 15,16539 & 43 & SIDO & 17,8272 & 6,764424 \\
\hline 10 & BTON & 36,2729 & 23,7434 & 27 & KIAS & 4,62963 & 2,280521 & 44 & SKBM & $-7,78453$ & 3,350137 \\
\hline 11 & CANI & 157,6669 & 817,217 & 28 & KOBX & 8,150222 & 9,834934 & 45 & SMRU & 39,82554 & 0,125532 \\
\hline 12 & CPIN & 41,25135 & 49,79395 & 29 & LION & $-12,7513$ & 1,241343 & 46 & SRTG & $-1,42908$ & 0,662048 \\
\hline 13 & DGYR & $-8,96066$ & 3,208029 & 30 & LPLI & $-10,923$ & 9,075393 & 47 & TOBA & 42,99012 & 21,5002 \\
\hline 14 & DVLA & 15,22017 & 2,225081 & 31 & MLIA & 39,43538 & 20,99682 & 48 & TPIA & 182,152 & 508,2396 \\
\hline 15 & ELSA & 17,02834 & 14,07681 & 32 & MMLP & $-13,2414$ & 0,109331 & 49 & UNVR & 10,34147 & 7,527312 \\
\hline 16 & EXCL & $-13,601$ & 8,723307 & 33 & $\mathrm{MYOH}$ & 26,79894 & 2,659962 & 50 & VOKS & 17,37609 & 5,334325 \\
\hline 17 & FAST & 14,13567 & 1,993122 & 34 & NELY & 7,246377 & 15,46244 & & & & \\
\hline
\end{tabular}

Sumber: Bursa Efek Indonesia (2020) diolah. 


\section{b. Risk dan Return Saham Konvensional}

Saham konvensional adalah surat berharga yang dikeluarkan oleh perusahaan berbentuk Perseroan Terbatas (PT) dan merupakan saham non-syariah, yaitu saham perusahaan yang melakukan kegiatan bertentangan dengan prinsip syariah, di antaranya adalah total pendapatan bunga emiten saham syariah dan pendapatan non-halal lainnya lebih kecil daripada total pendapatan usaha (revenue). Jadi, saham konvensional lebih banyak dilihat pada aktivitas kegiatannya atau jenis usaha dan industri.

Tabel 3 menunjukkan bahwa saham konvensional dengan risiko terbesar adalah saham PT Bank Rakyat Indonesia Agroniaga (AGRO) dengan risiko 337,7814\% dan saham dengan risiko terkecil adalah saham PT Asuransi Multi Artha Guna (AMAG) dengan risiko sebesar 0,466442\%. Beberapa saham dengan risiko di bawah satu adalah PT Asuransi Harta Aman Pratama (AHAP); PT Bank JTrust Indonesia (BCIC); PT Jakarta International Hotels \& Development (JIHD), dan PT Bentoel International Investama (RMBA) dengan risiko masing-masing adalah 0,572834\%; 0,00\%; $0,811203 \%$; dan $0,494758 \%$.

Tabel 3 juga menunjukkan hasil analisis estimasi estimasi return positif terbesar adalah saham PT Bank Rakyat Indonesia Agroniaga (AGRO) dengan estimasi return sebesar 130,1408\% dan saham dengan estimasi return positif terkecil adalah saham PT H.M. Sampoerna (HMSP) dengan estimasi return sebesar 1,265305\%. Selanjutnya, saham konvensional dengan estimasi return negatif terbesar adalah saham PT Wismilak Inti Makmur (WIIM) dengan estimasi return sebasar -27,7149\% dan saham dengan estimasi return negatif terendah adalah saham PT Asuransi Bina Dana Arta (ABDA) dengan estimasi return sebasar $-4,06675 \%$.

Tabel 3. Hasil Analisis Estimasi Risk dan Return Saham Konvensional

\begin{tabular}{|c|c|c|c|c|c|c|c|c|c|c|c|}
\hline No & Emiten & Est. Ret & Risiko & No & Emiten & Est. Ret & Risiko & No & Emiten & Est. Ret & Risiko \\
\hline 1 & ABDA & $-4,06675$ & 0,574008 & 18 & BCIC & 0 & 0 & 35 & HOME & $-14,5367$ & 11,04321 \\
\hline 2 & AGRO & 130,1408 & 337,7814 & 19 & BDMN & 37,54052 & 12,468 & 36 & HOTL & $-7,44657$ & 1,810575 \\
\hline 3 & AHAP & $-10,0445$ & 0,572834 & 20 & BFIN & 39,02661 & 16,50144 & 37 & INPP & 26,85259 & 4,885367 \\
\hline 4 & AMAG & $-4,7284$ & 0,466442 & 21 & BJBR & 101,7399 & 306,0604 & 38 & JIHD & $-5,43818$ & 0,811203 \\
\hline 5 & ASDM & 1,283404 & 1,393336 & 22 & BJTM & 17,39309 & 2,099714 & 39 & MAMI & 25,90864 & 24,38681 \\
\hline 6 & ASJT & 67,01733 & 126,6979 & 23 & BKSW & $-6,55544$ & 2,192605 & 40 & MLBI & 25,55916 & 1,573027 \\
\hline 7 & ASMI & 54,6321 & 30,0244 & 24 & BMRI & 18,51682 & 3,750918 & 41 & PGLI & 77,96445 & 59,74715 \\
\hline 8 & ASRM & 1,59502 & 1,738749 & 25 & BNBA & 14,3315 & 1,93816 & 42 & PNSE & 37,24593 & 46,63382 \\
\hline 9 & BABP & $-10,7794$ & 1,117156 & 26 & BNGA & 23,18597 & 15,87523 & 43 & PSKT & $-26,4807$ & 6,765448 \\
\hline 10 & BACA & 14,74369 & 2,946732 & 27 & BNII & 18,32039 & 32,40422 & 44 & RMBA & $-14,8268$ & 0,494758 \\
\hline 11 & $\mathrm{BBCA}$ & 25,51771 & 1,251798 & 28 & BNLI & $-6,24644$ & 4,692794 & 45 & SHID & 104,9413 & 26,39927 \\
\hline 12 & BBHI & 24,42886 & 24,79977 & 29 & BSWD & $-19,1592$ & 3,275324 & 46 & TFA & 6,068445 & 3,49911 \\
\hline 13 & BBKP & $-23,4274$ & 4,643337 & 30 & BTPN & 14,33974 & 3,722072 & 47 & TRUS & 24,63627 & 37,2082 \\
\hline 14 & BBNI & 26,94317 & 14,59564 & 31 & CFIN & 5,36075 & 1,669991 & 48 & VINS & 25,33354 & 55,53433 \\
\hline 15 & BBNP & 12,22538 & 11,69006 & 32 & DLTA & 2,593185 & 1,516393 & 49 & VRNA & $-6,25336$ & 6,384672 \\
\hline 16 & BBRI & 19,5421 & 6,609836 & 33 & GGRM & 15,70513 & 1,639303 & 50 & WIIM & $-27,7149$ & 5,010294 \\
\hline 17 & BBTN & 36,8946 & 29,96941 & 34 & HMSP & 1,265305 & 3,386262 & & & & \\
\hline
\end{tabular}

Sumber: Bursa Efek Indonesia (2020) diolah.

\section{Hasil Uji Beda}

Penelitian ini menganalisis perbedaan tingkat pengembalian (return) antara saham syariah dan konvensional yang aktif dan tercatat di Bursa Efek Indonesia menggunakan independent samples t-test. Uji independent sample t-test merupakan bagian dari statistik parametrik (uji beda atau uji perbandingan). 


\section{a. Hasil Uji Beda untuk Return}

Uji beda dalam independent sample t-test dilakukan untuk mengetahui perbedaan rata-rata return dan risk antara saham syariah dan konvensional. Syarat untuk melakukan uji beda independent sample t-test dengan mendasarkan pada hasil uji Levene's test for Equality of Variances (Santoso, 2014). Hasil uji independent sample t-test dalam perbandingan return saham syariah dan konvensional di BEI menunjukkan bahwa Levene's test for Equality of Variances sebesar 0,873 atau lebih besar daripada 0,05, sehingga hasil tersebut mengindikasikan bahwa varian kelompok saham syariah dan konvensional adalah homogen atau sama (Santoso, 2014). Hasil independent sample ttest pada bagian equal variances assumed menunjukkan bahwa nilai sig. (2-tailed) sebesar 0,935 yang lebih besar daripada 0,05. Hasil tersebut menunjukkan bahwa Ho diterima. Dengan demikian, penelitian ini menemukan tidak ada perbedaan signifikan antara rata-rata return saham-saham syariah dan konvensional yang tercatat di BEI.

Tabel 4. Independent Samples t-Test

\begin{tabular}{|c|c|c|c|c|c|c|c|c|c|c|}
\hline & & $\begin{array}{r}\text { Leven } \\
\text { for Eq } \\
\text { Vart } \\
\end{array}$ & $\begin{array}{l}\text { 's Test } \\
\text { ality of } \\
\text { nces }\end{array}$ & & & & -test for Equal & y of Means & & \\
\hline & & \multirow[b]{2}{*}{$\mathbf{F}$} & \multirow[b]{2}{*}{ Sig. } & \multirow[b]{2}{*}{$\mathbf{t}$} & \multirow[b]{2}{*}{ df } & \multirow{2}{*}{$\begin{array}{c}\text { Sig. } \\
\text { (2-tailed) }\end{array}$} & \multirow{2}{*}{$\begin{array}{c}\text { Mean } \\
\text { Difference } \\
\end{array}$} & \multirow{2}{*}{$\begin{array}{l}\text { Std. Error } \\
\text { Difference }\end{array}$} & \multicolumn{2}{|c|}{$\begin{array}{l}95 \% \text { Confidence } \\
\text { Interval of the } \\
\text { Difference }\end{array}$} \\
\hline & & & & & & & & & Lower & Upper \\
\hline \multirow[t]{2}{*}{ Return } & $\begin{array}{l}\text { Equal } \\
\text { variances } \\
\text { assumed }\end{array}$ & .026 & .873 & .082 & 98 & .935 & 4.14614 & 50.53121 & -96.13140 & 104.42368 \\
\hline & $\begin{array}{l}\text { Equal } \\
\text { variances not } \\
\text { assumed }\end{array}$ & & & .082 & 97.999 & .935 & 4.14614 & 50.53121 & -96.13141 & 104.42369 \\
\hline
\end{tabular}

Sumber: Bursa Efek Indonesia (2020) diolah.

Penelitian lain sebelumnya juga menyimpulkan hal yang sama, yaitu tidak ada perbedaan return saham syariah dan return saham konvensional (Rosyida \& Mawardi, 2015; Binangkit \& Savitri, 2016; Khaddafi \& Ferdiansyah, 2017; Qoonitah, 2018; Kasanah \& Worokinasih, 2018; Rukmini \& Pradana, 2019; Tendean, Saerang, \& Tulung, 2019). Investor melakukan kegiatan investasi lebih banyak mempertimbangkan risk dan return. Return yang melekat pada saham terdiri atas capital gain/loss dan deviden saham. Capital gain/loss merupakan selisih antara harga sekarang secara relatif terhadap harga periode sebelumnya, sedangkan deviden saham merupakan hasil atau tingkat keuntungan investasi pada saham ketika melewati tanggal pembayaran saham. Pada umumnya, dividen dibayarkan pada akhir tahun.

Saham-saham yang dimiliki oleh investor dalam struktur portofolio mereka lebih banyak dipilih dengan memperhatikan return dan risk secara invidual dengan penyebaran yang lebih mempertimbangkan rendahnya korelasi saham-saham secara individual. Hanya sedikit investor, terutama investor jangka panjang yang memperhatikan kriteria syariah dan konvensional. Sjahrir dalam Septyanto (2013) mengungkapkan bahwa investor di pasar modal berperilaku taking profit dengan memperhatikan capital gain (loss). Hal ini menunjukkan bahwa investor lebih menyukai investasi jangka pendek, perilaku spekulatif, dan melakukan strategi aktif dengan memperhatikan faktorfaktor makro, misalnya isu, rumor, politik, konspirasi, insider trading, regulasi, anomali pasar, dan lain-lain. 


\section{b. Hasil Uji Beda untuk Risk}

Hasil uji independent samples t-test untuk membandingkan risk antara saham syariah dan konvensional di BEI menunjukkan bahwa Levene's test for Equality of Variances sebesar 0,002 atau lebih kecil daripada 0,05. Hasil tersebut menunjukkan bahwa varian kelompok saham syariah dan konvensional bersifat heterogen atau tidak sama (Santoso, 2014). Berdasarkan ketentuan statistik, perbedaan risiko pada kedua saham yang diteliti tersebut tidak dapat dibandingkan (Santoso. 2014).

\section{KESIMPULAN}

Pada saham-saham syariah, hasil estimasi return tertinggi positif adalah saham PT Destinasi Tirta Nusantara (PDES) dengan estimasi return 166,33045\%, sedangkan hasil estimasi risiko terbesar juga saham PT Destinasi Tirta Nusantara (PDES) dengan risiko sebesar 334,031\%. Pada sisi lain, hasil estimasi return positif terbesar pada sahamsaham konvensional adalah saham PT BRI Agroniaga (AGRO) dengan estimasi return sebesar 130,1408\%, sedangkan hasil risiko terbesarnya juga saham PT BRI Agroniaga (AGRO) dengan risiko sebesar 337,7814\%.

Dari hasil analisis uji beda menunjukkan bahwa tidak ada perbedaan signifikan antara rata-rata return saham-saham syariah dan konvensional yang ada di BEI. Dalam struktur portofolio, secara umum investor lebih banyak memperhatikan return sebagai tingkat pengembalian investasinya dan risk yang harus ditanggung melekat pada saham secara invidual, dan penyebaran yang lebih mempertimbangkan rendahnya korelasi saham-saham secara individual.

\section{DAFTAR REFERENSI}

Al-Nisa, Q. F. (2018). Perbandingan antara Return Saham Syariah dan Saham Konvensional di Bursa Efek Indonesia (Pendekatan Vektor Error Correction Model). Inklusif: Jurnal Pengkajian Penelitian Ekonomi dan Hukum Islam, 3(2), $135-146$.

Arikunto, A. (2002). Prosedur Penelitian, Suatu Pendekatan Praktek. Jakarta: PT Rineka Cipta.

Binangkit, I. D., \& Savitri, E. (2016). Analisis Perbandingan Kinerja Saham-saham Syariah dan Saham-saham Konvensional pada Portofolio Optimal dengan Pendekatan Single Index Model (Studi Kasus pada Bursa Efek Indonesia Tahun 2013-2015). Jurnal Tepak Manajemen Bisnis, VIII(3), 1-17.

Bursa Efek Indonesia (2020). Pengantar Pasar Modal. Diakses pada tanggal 10 Oktober 2020 di https://www.idx.co.id/investor/pengantar-pasar-modal.

Fahmi, F. (2012). Pengantar Manajemen Keuangan: Teori dan Soal Jawab. Bandung: Alfabeta.

Faqih, A. (2018). Praktik Jual Beli Saham Syari'ah Perspektif Hukum Islam. Jurnal Jurnal Iqtisad: Reconstruction of Justice and Welfare for Indonesia, 5(1), 43-74.

Fraenkel, J. \& Wallen, N. (1993). How to Design and Evaluate Research in Education. Second Edition. New York: McGraw-Hill, Inc. 
Hamidi, H. (2004). Metode Penelitian Kualitatif: Aplikasi Praktis Pembuatan Proposal dan Laporan Penelitian. Malang: UMM Press.

Hanafi, M. M., \& Halim, A. (2012). Analisis Laporan Keuangan. Edisi Ketiga. Cetakan Pertama. Yogyakarta: BP STIM YKPN.

Hidayat, H (2011). Buku Pintar Investasi Syariah. Jakarta: PT TransMedia.

Husnan, S. (2008). Manajemen Keuangan: Teori dan Penerapan. Buku 1. Edisi ke-4. Yogyakarta: BPFE.

Jogiyanto, H. (2008). Teori Portofolio dan Analisis Investasi. Edisi Ketiga. Cetakan Pertama. Yogyakarta: BPFE.

Kasanah, H. R., \& Worokinasih, S. (2018). Analisis Perbandingan Return dan Risk Saham Syariah dengan Saham Konvensional (Studi pada Jakarta Islamic Index (JII) dan IDX30 Periode 2014-2016). Jurnal Administrasi Bisnis, 58(2), 46-55.

Khaddafi, M. \& Ferdiansyah, F. (2017). Analisis Perbandingan Return dan Risk (Studi pada Saham Syariah dan Saham Konvensional LQ45 Periode (2012-2016). Jurnal Akuntansi dan Keuangan, 5(1), 33-37.

Listyawati, L., \& Nurchayati, N. (2020). Analisa Perbandingan Risk dan Return pada Investasi Saham Syariah dan Konvensional (Studi pada Jakarta Islamic Index (JII) dan Indeks LQ45 Periode 2016-2019). Serat Acitya, 1(1), 1-12.

Majelis Ulama Indonesia (2011). Fatwa Nomor 80/DSN-MUI/III/2011 tentang Penerapan Prinsip Syariah dalam Mekanisme Perdagangan Efek Bersifat Ekuitas di Pasar Reguler Bursa Efek. Diakses di https://tafsirq.com/fatwa/dsnmui/penerapan-prinsip-syariahdalam-mekanisme-perdagangan-efek-bersifatekuitasdi-pasar-reguler-bursa-efek.

Majelis Ulama Indonesia (2013). Fatwa Nomor 40/DSN-MUI/X/2003 tentang Pasar Modal dan Pedoman Umum Penerapan Prinsip Syariah di Bidang Pasar Modal. Diakses di https://tafsirq.com/fatwa/dsn-mui/pasar-modal-dan-pedoman-umumpenerapan-prinsip-syariah-di-bidang-pasar-modal.

Muthoharoh, M., \& Sutapa, S. (2014). Perbandingan Saham Berbasis Syariah dengan Saham Konvensional sebagai Analisis Kelayakan Investasi bagi Investor Muslim. Jurnal Akuntansi Indonesia, 3(2), 101-112.

Otoritas Jasa Keuangan (2020a). Undang-Undang Pasar Modal Nomor 8 Tahun 1995 tentang Pasar Modal. Diakses tanggal 27 Desember 2020 di https://www.ojk.go.id/id/kanal/pasar-modal/regulasi/undangundang/Documents/Pages/undang-undang-nomor-8-tahun-1995-tentang-pasarmodal/UU\%20Nomor\%208\%20Tahun\%201995\%20(official).pdf.

Otoritas Jasa Keuangan (2020b). Peraturan Otoritas Jasa Keuangan Nomor 35/POJK.04/2017 tentang Kriteria dan Penerbitan Daftar Efek Syariah. Diakses 27 Desember 2020 di https://www.ojk.go.id/id/kanal/pasarmodal/regulasi/peraturan-ojk/Documents/Pages/Peraturan-Otoritas-JasaKeuangan-Nomor-35-POJK.04-2017-/SAL\%20POJK\%2035\%20-\%20DES.pdf.

Otoritas Jasa Keuangan (2020c). Keputusan Dewan Komisioner OJK Nomor KEP24/D.04/2018 tentang Daftar Efek Syariah. Diakses tanggal 27 Desember 2020 di https://www.ojk.go.id/id/kanal/syariah/data-dan-statistik/daftar-efeksyariah/Pages/Keputusan-Dewan-Komisioner-OJK-Nomor-KEP-24-D.04-2018tentang-Daftar-Efek-Syariah.aspx. 
Pardosi, B., \& Wijayanto, A. (2015). Analisis Perbedaan Return dan Risiko Saham Portofolio Optimal dengan Bukan Portofolio Optimal. Management Analysis Journal, 4(1), 1-9.

Rosyida, A. G., \& Mawardi, I. (2015). Perbandingan Tingkat Pengembalian (Return), Risiko dan Koefisien Variasi pada Saham Syariah dan Saham Non Syariah di Bursa Efek Indonesia (BEI) Periode 2011-2013. Jurnal Ekonomi Syariah Teori dan Terapan, 2(4), 288-304.

Rukmini, D., \& Pradana, M. N. R. (2019). Analisis Perbandingan Tingkat Pengembalian dan Risiko antara Indeks Saham Syariah dan Indeks Saham Konvensional di Bursa Efek Indonesia. Jurnal Manajemen dan Keuangan, 8(3), 300-312.

Santoso, S. (2014). Statistik Parametrik. Edisi Revisi. Jakarta: PT Elex Media Komputindo (Kelompok Gramedia).

Santoso, S. (2015). SPSS 20 Pengolahan Data Statistik di Era Informasi. Jakarta: PT Elex Media Komputindo (Kelompok Gramedia).

Sartono, S. (2008). Manajemen Keuangan Teori dan Aplikasi. Edisi Keempat. Yoyakarta: BPFE.

Septyanto, D. (2013). Faktor-Faktor yang Mempengaruhi Investor Individu dalam Pengambilan Keputusan Investasi Sekuritas di Bursa Efek Indonesia (BEI). Jurnal Ekonomi, 4(2), 90-101.

Sugiyono, S. (2007). Metode Penelitian Kuantitatif, Kualitatif, dan R\&D. Bandung: Alfabeta.

Sutedi, S (2011). Pasar Modal Syariah. Jakarta: Sinar Grafika.

Tandelilin, E. (2001). Analisis Investasi dan Manajemen Portofolio. Yogyakarta: BPFE.

Tendean, Y. P. J., Saerang, I. S., \& Tulung, J. E. (2019). Analisis Perbandingan Risiko Saham Jakarta Islamic Index dan Indeks LQ45 di Bursa Efek Indonesia (Comparison Analysis Stock Risk of Jakarta Islamic Shares Index and LQ45 Index in Indonesia Stock Exchange). Jurnal EMBA, 7(6), 3239-3248.

Umam, K. (2013). Pasar Modal Syariah \& Praktek Pasar Modal Syariah. Bandung: Pustaka Setia. 